\title{
A novel, Eco-friendly and Economical Process for Desalination of Water using Waste Food Materials
}

\author{
RUNJHUN TANDON ${ }^{1}$, STANZIN LZAOD'1, MANDEEP SINGH'1, NITIN TANDON1, \\ AGNIBHA DAS MAJUMDAR ${ }^{2}$, SOUMAVA SANTRA ${ }^{1}$ and TANAY PRAMANIK ${ }^{3 *}$
}

'Department of Chemistry, School of Chemical Engineering and Physical Science. Faculty of Technology and Sciences, Lovely Professional University, Phagwara, P. O. Box 144411, India.

${ }^{2}$ Department of Physics, School of Chemical Engineering and Physical Science. Faculty of Technology and Sciences, Lovely Professional University, Phagwara, P. O. Box 144411, India. ${ }^{3}$ Department of Chemistry, University of Engineering and Management, University Area, Action Area III, B/5, Newtown, Kolkata-700160, India.

${ }^{*}$ Corresponding author E-mail: tanay.pramanik@gmail.com

http://dx.doi.org/10.13005/ojc/370302

(Received: April 01, 2021; Accepted: May 02, 2021)

\section{ABSTRACT}

Scarcity of water in this world can be solved by removal of salinity from sea-water but this salinity removal is usually a costly and tedious task. In this work an efficient process has been developed for desalination of water using food waste materials which is completely eco-friendly and economic. A large number of starch rich food materials have been employed for the purpose of desalination of water and it was observed that all of them are effective to remove the salt contained from water, however it was observed that all of those food materials were not equally effective to remove salt contained. Cornflour was seen to be most effective which can remove salinity from sea water up $75-80 \%$. This technology has a great prospect to evolve as a novel and green method for the purpose of desalination of water in near future.

Keywords: Salinity, Desalination, Eco-friendly, Food, Water.

\section{INTRODUCTION}

Water is indisputably the most basic and vital component of life. It is also essential for cooking, health, sanitation and various other things. $97.5 \%$ of the total volume of water available on earth is salt water and only $2.5 \%$ is freshwater; even then, only $0.3 \%$ of this freshwater is fit for our daily consumption. ${ }^{1}$ According to the World Health
Organization, more than 2.1 billion people have no access to clean and safe drinking water. ${ }^{2}$ Due to this, water scarcity is one of the most critical and pressing environmental issues today. Therefore, many innovators and researchers are developing technologies to cope with this crisis resourcefully.

It is well known that salt water is injurious to health and unfit for agriculture, industrial and

This is an Open Access article licensed under a Creative Commons license: Attribution 4.0 International (CC- BY). Published by Oriental Scientific Publishing Company @ 2018

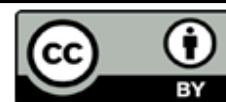


domestic use. Desalination is usually carried out using energy intensive processes like reverse osmosis. These conventional techniques ${ }^{3-12}$ of desalination are hazardous to the environment in some way or the other. Although, there have been efforts to make these processes environmentally friendly; however, the findings of a study involving only eco-friendly materials without the use of energy or any chemical reagents for removal of salinity of water are not known and not documented standardly. Therefore, a greener and more sustainable approach to water desalination needs to be developed.

Salinity is the measure of all the salts dissolved in water and it is measured in parts per thousand (g per 1000 grams)..$^{13-17}$

Thermal distillation and membrane technologies are the two technologies that are extensively used for desalination today. Both technologies require energy to operate and produce freshwater.

The conventional method of desalination is having several disadvantages like- it requires high temperature, wastage of water, lack of efficiency and it has adverse impact on environment. Thus there was a need of development of a eco-friendly technology for desalination of water.

\section{Methodology}

Salinity of water is measured in parts per thousand, more commonly known as practical salinity unit and can be measured using a digital salinity water. It is a solid state instrument which is designed to carry out precise salinity measurements.

Principle of operation of digital salinity meter-the digital salinity meter consists of a salinity cell which is dipped in a measuring solution. When an AC voltage of constant amplitude and suitable frequency is applied to the system, the output is linearly proportional to the conductance of the solution. The conductance value is normally required to be multiplied by the cell constant of the solution to convert into salinity unless provision already exist in the instrument to compensate for the same. Thus the output indicates directly, the salinity of the solution under test.

\section{Calibration of the salinity meter ${ }^{21}$}

1. Connect the instrument to the AC mains supply and allow it to warm for a few minutes.

2. Connect the salinity cell on the back panel.

3. Put the function switch to CAL position. See that the display reads 1.000 . If not, then adjust it to 1.000 with the help of the control provided at the back panel.

4. Now put the function switch to Cell Const position. See that the display reads 1.000 . If not, then adjust it to 1.000 with the help of the control provided at the front panel.

5. Standard saline water (15ppt and 20ppt) is used for calibration of the instrument.

6. Repeat this calibration procedure two times.

\section{Column packing for continuous desalination}

1. A continuous desalination method is adopted using a column of length $10 \mathrm{~cm}$ and radius $1.25 \mathrm{~cm}$.

2. Various starch rich materials (the material under consideration) were cut/grinded into small pieces (preferably turned in powdered form) and those are used for packing the column.

3. At the bottom of the column, a small piece of cotton is fitted. Above that, a very fine layer of sand is used to restrict the contact between the cotton and leaves or peels.

4. The small pieces of leaves and peels are then used to fill the column so that the length of the column is $10 \mathrm{~cm}$.

5. Finally, the column is packed with another small piece of cotton at the top.

\section{Continuous desalination using eco-friendly materials}

1. Saline water with initial salinity of $20 \mathrm{ppt}$ is poured in the column.

2. The rate of flow of water is fixed to 1 drop per minute $/ 0.05 \mathrm{~mL}$ per minute.

3. The water is collected in a beaker.

\section{Determination of salinity}

1. The salinity of the water collected after continuous softening is then determined using a digital salinity meter. 
2. Calibrate the instrument.

3. Wash the dipping cell with distilled water.

4. Dip the cell in the collected water and record the salinity of the collected water.

\section{RESULT AND DISCUSSION}

Various starch rich materials were used for the purpose of desalination and it was observed that the different materials were having different efficiency in terms of their desalination capacity. All the obtained results are summarized below in tabular form.

The results in Table 1 show that various household materials can be used for desalination. Graph 1 establishes that there is a direct correlation between starch content and desalination efficiency. Starch is a carbohydrate that is made up of several glucose units.

Table 1: Continuous desalination with various eco-friendly materials

\begin{tabular}{|c|c|c|c|c|c|c|}
\hline S. No. & Material used & $\begin{array}{l}\text { Starch content } \\
\quad(\mathrm{g} / 100 \mathrm{~g})\end{array}$ & $\begin{array}{l}\text { Initial salinity } \\
\quad(p p t)\end{array}$ & $\begin{array}{l}\text { Final salinity } \\
\text { (ppt) }\end{array}$ & $\begin{array}{c}\text { Difference } \\
\quad(p p t)\end{array}$ & $\begin{array}{c}\text { Percentage } \\
\text { efficiency (\%) }\end{array}$ \\
\hline 1 & Cornflour (Zea mays) & 92.0 & 20.0 & 4.92 & -15.08 & $75.4 \%$ \\
\hline 2 & Raw white potato (Solanum tuberosum) & 19.6 & 20.0 & 6.15 & -13.85 & $69.2 \%$ \\
\hline 3 & Parboiled white rice (Oryza sativa) & 78.7 & 20.0 & 10.5 & -9.5 & $47.5 \%$ \\
\hline 4 & Raw semolina pasta & 73.6 & 20.0 & 15.62 & -4.38 & $21.9 \%$ \\
\hline 5 & Soybean (Glycine max) & 12.3 & 20.0 & 19.82 & -0.18 & $0.9 \%$ \\
\hline 6 & Peanut (Arachis hypogaea) & 3.66 & 20.0 & 19.91 & -0.09 & $0.45 \%$ \\
\hline 7 & Raw Sago (Metroxylon sagu) & 94.0 & 20.0 & 9.12 & -10.88 & $54.4 \%$ \\
\hline 8 & Raw white rice (Oryza sativa) & 85.8 & 20.0 & 10.23 & -9.77 & $48.85 \%$ \\
\hline 9 & Sand (control) & - & 20.0 & 20.0 & 0 & - \\
\hline
\end{tabular}

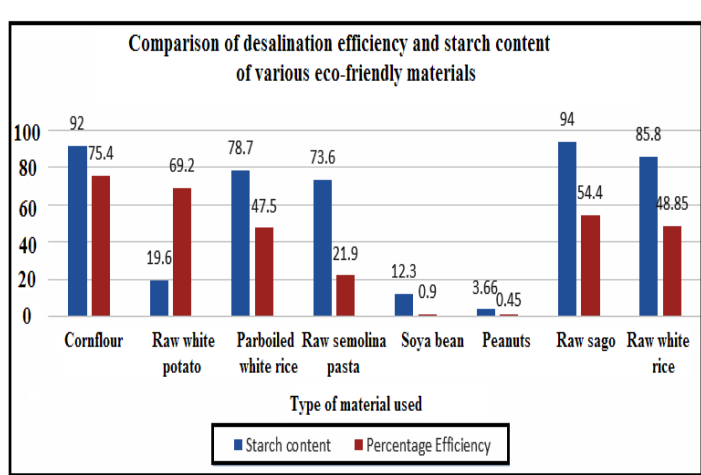

Fig.1.Comparison of desalination efficiency and starch content of various eco-friendly materials
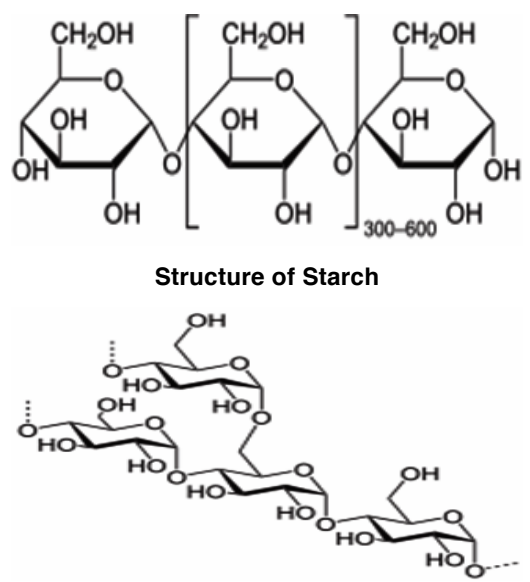

Structure of amylopectin
Explanation for desalination using starch containing food items

Researches ${ }^{37}$ have shown that hydroxyl groups that are present in carbohydrates can coordinate with metal cations. There has also been an effort to prove the existence of such a complex formation between the hydroxyl of carbohydrates and cation through electrophoresis. In solution containing cations, carbohydrates were shown to migrate towards the cathode thus highlighting the presence of a complex formation with the cation. This method was also used for electrophoretic separation of carbohydrates. The ionic radii of the cations were found to play a crucial role in affecting the tendency of forming complex with a carbohydrate. Researchers found that the most suitable ionic radius for complex formation is $100-110 \mathrm{pm}$. Sodium has an approximate ionic radius of $102 \mathrm{pm}$ while magnesium has an ionic radius of $72 \mathrm{pm}$. This explains why the starch containing materials are efficient at removing salt from water (Table 2). The poor efficiency of low starch content materials like peanuts and soya bean at removing salt from water also supports this hypothesis. When only sand was used (as a control), no reduction in salinity was observed, thus eliminating the possibility of sand removing salt from water. Amylopectin having lager hydroxyl units bonds with sodium more effectively than starch as confirmed from our experimental data. 
Table 2: Effect of size of the column on the efficiency of desalination

\begin{tabular}{|c|c|c|c|c|c|c|}
\hline Material used & $\begin{array}{l}\text { Length of the } \\
\text { column }(\mathrm{cm})\end{array}$ & $\begin{array}{l}\text { Radius of the } \\
\text { column }(\mathrm{cm})\end{array}$ & $\begin{array}{l}\text { Initial salinity } \\
\quad(p p t)\end{array}$ & $\begin{array}{l}\text { Final salinity } \\
\quad(p p t)\end{array}$ & $\begin{array}{l}\text { Difference } \\
\quad(p p t)\end{array}$ & $\begin{array}{c}\text { Percentage } \\
\text { Efficiency (\%) }\end{array}$ \\
\hline Raw white potato & 10.0 & 1.25 & 20.0 & 6.15 & -13.85 & $69.2 \%$ \\
\hline Raw white potato & 20.0 & 0.8 & 20.0 & 9.24 & -10.76 & $53.8 \%$ \\
\hline
\end{tabular}

Although, corn flour had the highest efficiency, raw white potato was used to study the effect of size of the column on the efficiency of desalination. Corn flour with its very fine grain size made it harder to control the rate of flow of water through it in different columns, thus raw white potato was utilized to study the effect of size of column on efficiency of desalination. It was observed that a shorter column with a bigger radius has better efficiency at desalination than a longer column with smaller radius. With raw white potato, the shorter column with larger radius showed almost 15 better efficiencies than a longer column with smaller radius.

Table 3: Effect of grain size of the material used on the efficiency of desalination

\begin{tabular}{|c|c|c|c|c|c|}
\hline Material used & Size (microns) & Initial salinity (ppt) & Final salinity (ppt) & Difference (ppt) & Percentage Efficiency (\%) \\
\hline Raw sago & 355.0 & 20.0 & 9.68 & -10.32 & $51.6 \%$ \\
\hline Raw sago & 180.0 & 20.0 & 9.12 & -10.88 & $54.4 \%$ \\
\hline Raw white rice & 710.0 & 20.0 & 17.10 & -2.9 & $14.5 \%$ \\
\hline Raw white rice & 180.0 & 20.0 & 10.23 & -9.77 & $48.85 \%$ \\
\hline
\end{tabular}

It can be observed that a smaller grain size ensures better efficiency at desalination. This can be explained on the basis of surface area concept. A smaller size of grain has a greater surface area, thus increasing the complexation between the hydroxyl group of starch and sodium. Thus, an increase in efficiency is observed with decrease in size of the grain.

\section{Shelf-life of sago for desalination}

Although, corn flour showed the highest efficiency, this efficiency was not long-lasting. When corn flour was used to study the shelf-life, it could only last one day and purify only $20 \mathrm{~mL}$ of water. Raw white potato had the next best efficiency but because raw potato cannot be stored for very long, sago was used for studying the shelf-life of the bio-filter.

Table 4: Percentage efficiency of sago used for desalination in terms of volume per day

\begin{tabular}{ccccc}
\hline Volume $(\mathrm{mL})$ & Initial salinity (ppt) & Final salinity (ppt) & Difference (ppt) & \% Efficiency \\
\hline 20.0 & 20.0 & 9.1 & -10.9 & $54.5 \%$ \\
40.0 & 20.0 & 13.8 & -6.2 & $31.0 \%$ \\
60.0 & 20.0 & 15.5 & -4.5 & $22.5 \%$ \\
80.0 & 20.0 & 19.6 & -0.4 & $2 \%$ \\
100.0 & 20.0 & 19.9 & -0.1 & $0.5 \%$ \\
\hline
\end{tabular}

Percentage Efficiency of sago for desalination in terms fo volume

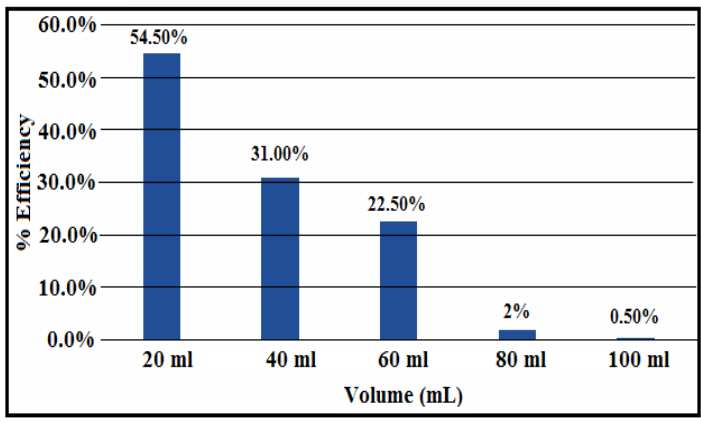

Fig. 2. Graphical representation of percentage efficiency of sago used for desalination in terms of volume per day
The same column packed with sago was used to purify $100 \mathrm{~mL}$ of sample saline water on one particular day. It can be concluded from graph 2 that sago column can purify at least $60 \mathrm{~mL}$ of water in a day with significant efficiency. After $60 \mathrm{~mL}$ of water has been passed through the column, the efficiency of the column reduces significantly.

The same column packed with sago was used over a course of four days. A decrease in efficiency for desalination was observed with each day. In addition to this, it was observed that the sago column possesses significant efficiency at 
desalination up to two days. After the second day, that a column packed with sago can be used for there is a drastic reduction in efficiency. This implies

desalination for at least two days.

Table 5: Percentage efficiency of sago used for desalination in terms of days

\begin{tabular}{ccccc}
\hline Day & Initial salinity (ppt) & Final salinity (ppt) & Difference (ppt) & Percentage Efficiency (\%) \\
\hline 1 & 20.0 & 9.1 & -10.9 & $54.5 \%$ \\
2 & 20.0 & 14.3 & -5.7 & $28.5 \%$ \\
3 & 20.0 & 19.5 & -0.5 & $2.5 \%$ \\
4 & 20.0 & 20.0 & 0 & $0 \%$ \\
\hline
\end{tabular}

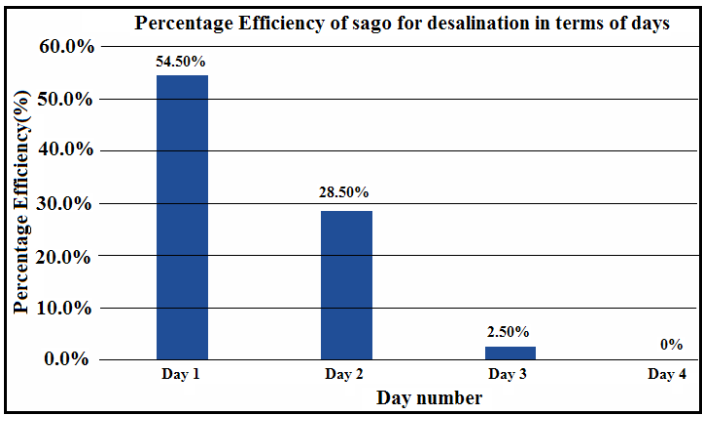

Fig. 3. Graphical representation of percentage efficiency of sago for desalination in terms of number of days

\section{Batch Desalination}

After getting the result of continuous desalination using column, a batch desalination was also performed. In this batch desalination process the starch balls were made and put into saline water to remove salinity. Various balls of various size were used and the results are summarized in Table 6.

Thus after observing this result from Table 6 , rest all of the batch desalinations were carried out by using pure starch material without adding any silica gel. Addition of silica gel did not favor the removal of salt from water. The balls with pure lab starch gave the best results.

Table 6: Batch desalination result with the balls made from starch (with and without silica gel)

\begin{tabular}{|c|c|c|c|}
\hline Material $20 \mathrm{~g}$ balls $/ 20 \mathrm{ppt} / 100 \mathrm{~mL}$ & Initial salinity & Final salinity after $5 \mathrm{~h}$ & $\%$ Decrease of salinity \\
\hline Starch & 20 ppt & $15 \mathrm{ppt}$ & $15 \%$ \\
\hline Starch extract+Silica Gel & $20 \mathrm{ppt}$ & $18 \mathrm{ppt}$ & $10 \%$ \\
\hline Sago & $20 \mathrm{ppt}$ & 17.2 & $14 \%$ \\
\hline Starch extracted from Sago+Silica Gel & $20 \mathrm{ppt}$ & 19.0 & $5 \%$ \\
\hline
\end{tabular}

Table 7: Desalination using various amount of desalinating material (corn flour ball) against various concentration of saline water

Time $20 \mathrm{ppt}$ saline water $+20 \mathrm{~g}$ balls $30 \mathrm{ppt}$ saline water $+20 \mathrm{~g}$ ball $20 \mathrm{ppt}$ saline water $+30 \mathrm{~g}$ ball $20 \mathrm{ppt}$ saline water $+40 \mathrm{~g}$ ball

\begin{tabular}{lcccc}
\hline 0 hour & $20 \mathrm{ppt}$ & $30 \mathrm{ppt}$ & $20 \mathrm{ppt}$ & $20 \mathrm{ppt}$ \\
1 hour & $19.1 \mathrm{ppt}$ & 28.8 & $19 \mathrm{ppt}$ & $19.3 \mathrm{ppt}$ \\
2 hour & $18.7 \mathrm{ppt}$ & 28.2 & $18.2 \mathrm{ppt}$ & 16.8 \\
3 hour & $18.5 \mathrm{ppt}$ & 27.7 & $17.3 \mathrm{ppt}$ & 14.1 \\
4 hour & $18.3 \mathrm{ppt}$ & 27.4 & $16.7 \mathrm{ppt}$ & $13 \mathrm{ppt}$ \\
5 hour & $17.1 \mathrm{ppt}$ & $26.3 \mathrm{ppt}$ & $15 \mathrm{ppt}$ & $11.0 \mathrm{ppt}$ \\
\hline
\end{tabular}

Finally various different starch containing materials were used for making balls and desalination was carried out using the same. It was interesting to note that all those balls were made by using pure materials without adding any silica gel and all the balls were air dried (not oven dried). Moreover all the experiments were carried out with $20 \mathrm{ppt}$ saline water and $40 \mathrm{gm}$ balls. It was observed that corn flour was most effective among all of them in doing desalination of saline water. The results are depicted in Table 5 and 6.

It was observed that corn flour ball can reduce the salinity by $45 \%$ after $5 \mathrm{~h}$ whereas Sago can remove the salinity by only $25 \%$ after 5 hours. The mixture of sago + commercially available starch and corn + commercially available starch were also used as desalinating material but it was observed that pure corn flour is more effective than the mixtures. 
Table 8: $20 \mathrm{ppt}$ saline water solution $(100 \mathrm{~mL})+\mathbf{4 0} \mathrm{g}$ of air dried balls made with different material

\begin{tabular}{llccc}
\hline Material & Time & Intail ppt & Final ppt & Reduction of Salinity\% \\
\hline Pure starch & $5 \mathrm{~h}$ & $20 \mathrm{ppt}$ & $12.4 \mathrm{ppt}$ & $38 \%$ \\
Sago & $5 \mathrm{~h}$ & $20 \mathrm{ppt}$ & $15 \mathrm{ppt}$ & $25 \%$ \\
Corn flour & $5 \mathrm{~h}$ & $20 \mathrm{ppt}$ & $11 \mathrm{ppt}$ & $45 \%$ \\
Mix(sago+starch) & $5 \mathrm{~h}$ & $20 \mathrm{ppt}$ & $13.6 \mathrm{ppt}$ & $32 \%$ \\
Mix(corn+starch) & $5 \mathrm{~h}$ & $20 \mathrm{ppt}$ & $12 \mathrm{ppt}$ & $40 \%$ \\
\hline
\end{tabular}

Finally, after comparing the batch desalination and continuous desalination it was observed that the continuous desalination using column was more effective than batch desalination using starch ball provided that the desalinating material was pure corn in all these cases while doing comparison.

\section{CONCLUSION}

Based on the observations, it can be concluded that salinity of water can be removed using only naturally occurring materials without the application of any energy or chemical reagents. It was worthy to note that corn was most effective in desalination and the continuous desalination using starch column was more fruitful than the batch desalination using starch balls. It was interesting to note that food items with high starch content are more efficient at desalination and food items that have very low starch content are inefficient. The advantages of this technique are (1) no chemical reagents are needed, (2) no energy is required, (3) it is eco-friendly, (3) it is cost-effective, (5) it is simple and efficient. The development of such a green technique will simplify the water softening process and desalination without any damage to the environment; removing permanent hardness and desalination with eco-friendly materials is thus likely to become a widespread method in the near future. A biofilter can be made very efficiently to desalinate water and use it for household purposes like bathing, watering plants, washing and many more activities.

\section{ACKNOWLEDGEMENT}

The authors are thankful to the Lovely Professional University and University of Engineering and Management Kolkata for the technical and financial support in this project.

\section{Conflict of Interest}

Declared None.

\section{REFERENCES}

1. a) Palanna, O. G. "Water Technology." In Engineering Chemistry, by Palanna O.G., 259-308. New Delhi: Tata McGraw Hilll Education Private Limited, 2009. b) World Health Organization. "Comprehensive guideline for prevention and control of dengue and dengue haemorrhagic fever., 2011.

2. Zhang.; Xin-Rong.; JiaTing Fu and Yong Liu. Energy Solutions to Combat Global Warming. Springer, Cham., 2017, 307-327. Xiaolei Q., Pedro J. J. Alvarez, and Qilin L. Water res., 2013, 47, 3931-3946.

3. Bin Marshad.; Saud Mohammed H. Economic evaluation of seawater desalination: a case study analysis of cost of water production from seawater desalination in Saudi Arabia. Diss. Heriot-Watt University., 2014.

4. Alam, I. and Malik A. The Palgrave Handbook of Corporate Social Responsibility, 2020, 1-34.

5. $\quad$ Ali, M. H. "Water: an element of irrigation." Fundamentals of Irrigation and On-farm Water Management. Volume 1. Springer, New York, NY., 2010, 271-329.

6. Fatoba.;Ojo Olanrewaju. Chemicalinteractions and mobility of species infly ash-brine codisposal systems. Diss. University of the Western Cape., 2010.

7. Davis, C.; Hist Phil Sci Tech., 2010, IV, 308.

8. Alam, I., and MalikA. The Palgrave Handbook of Corporate Social Responsibility., 2020, 1-34.

9. Tabrizi.; Fardin, and Mohammad Taghi. Decolouration of reactive dyes with ozone in a semi-batch and a continuous stirred tank reactor. Diss., 2013. 
10. Wagutu, Agatha W. Study of crustacean biomass wastes for water defluoridation. Diss. NM-AIST., 2018.

11. Sengupta P. Int. J Prevent Med., 2013, 866-875. https://www.ncbi.nlm.nih.gov/pmc/ articles/PMC3775162/.

12. Li, Na, John J. Hefferren, and Ke'an Li. Quant Chem Anal., 2009, 137-138. Peking University Press.

13. Millero, Frank J., "The composition of Standard Seawater and the definition of the Reference-Composition Salinity Scale." Deep Sea Research Part I: Oceanographic Research Papers 55.1., 2008, 50-72.

14. Nayar, Kishor G., "Cost and energy requirements of hybrid $\mathrm{RO}$ and ED brine concentration systems for salt production." Desalination., 2019, 456, 97-120.

15. Adimalla N.; Peiyue L., and Venkatayogi S., Environ Proc., 2018, 5, 363-383.

16. Schwarzenbach, René P., Annu Rev Environ Resour., 2010, 35, 109-136.

17. Ghaffour, N.; Thomas M. M., and Gary L. A. Desalination., 2013, 309, 197-207.

18. Aende A.; Jabbar G., and Hassanpour A, Processes., 2020, 8, 901.

19. Malaeb L., and George M. A. , Desalination., 2011, 267, 1-8.

20. Eltawil, Mohamed A.; Zhao Z., and Liqiang Y. Renewable Sustainable Energy Rev., 2009, 13, 2245-2262.

21. Huber.; Christian, Fresenius' J Anal Chem., 2000, 368, 196-202.

22. Schaep J.; Van der Bruggen B.; Uytterhoeven S.; Croux R.; Vandecasteele C.; Wilms D.; Houtte E.V. \& Vanlerberghe F., DesalinationElsevier., 1998, 119, 295-302. https://doi. org/10.1016/S0011-9164(98)00172-6.

23. Mohammed, A.W.; N Hilal.; H. Al-Zoubib.; N.A. Darwish, and N. Ali. Desalination-Elsevier. 2007, 206, 215-225. https://doi.org/10.1016/j. desal.2006.02.068.

24. Altundogan H. S.; Aykut T.; Meltem C and Nurdan B.; J Taiwan Inst Chem Eng., 2016, 58, 219-225. https://doi.org/10.1016/j. jtice.2015.07.002.

25. Pentamwa P.; Wipasinum T and Suparat N. Int J Env Sci Dev II., 2011, 6, 479-483. 10.7763/ IJESD.2011.V2.173.

26. Rolence.; Cecilia.; Revocatus L. Machunda, and Karoli N. Njau. Res J Eng Appl Sci., 2014, 3, 199-207. https://www.scribd.com/ document/393285588/Potentials-Of-AgricWastes-Activated-Carbons-for-Water.

27. Kar S., and Tewari P. K.. nanotoday., 2012, 7, 385-389. https://doi.org/10.1016/j. nantod.2012.09.002.

28. Luo T.; Bajpayee A.; and Gang C. J Appl Phys., 2011, 110, 054905 https://doi. org/10.1063/1.3627239

29. Naim M, Mahmoud E.; Ahmed El-S, and Abeer M. Water Sci Technol., 2015, 72, 785793. doi: 10.2166/wst.2015.277.

30. HabelJ.; Michael H.;Soren K.; Nanna L,.; Soren R. M., and Grethe V. J. , Membranes., 2015, 5, 307-351. 10.3390/membranes5030307

31. Mallampati.; Ramakrishna, and Suresh Valiyaveettil. ACS Appl Mater Interfaces., 2013, 5, 4443-4449. 10.1021/am400901e.

32. Kanyal.; Mrinalini, and Anuja Ashok Bhatt. J Bioremediat Biodegrad., 2015, 6, 10.4172/2155-6199.1000269.

33. Wankhade.; Rajesh R. IOSR J Appl Chem., 2016, 9, 38-39. 10.9790/5736-0903013839

34. D'Aquino, M, and SA Tevas. Bull Pan Am Health Organ., 1994, 28, 324-330. PMID: 7858646.

35. Al-Rawahi.; Amani S.; Giles Edwards, Mohammed Al-Sibani, Ghanim Al-Thani, Ahmed S. Al-Harrasi, and Mohammed S. R., Eur J Med Plants., 2014, 4, 315-331. 10.9734/EJMP/2014/6417.

36. Fatemeh, S.R.; Saifullah R, Abbas F.M.A., and Azhar M.E., Int. Food Res J., 2012, 19, 1041-1046. http://www.ifrj.upm.edu. my/19\%20(03)\%202012/(35)\%20IFRJ\%20 19\%20(03)\%202012\%20Azhar.pdf.

37. Angyal, Stephen J., Adv Carbohyd Chem Bi., 1989, 47, 1-43. https://doi.org/10.1016/ S0065-2318(08)60411-4. 